\title{
Optimization of $\beta$-1,4-endoxylanase production by a new Aspergillus niger strain growing on wheat straw and application in xylooligosaccharides production
}

\author{
Zahra AZZOUZ ${ }^{1}$, Azzeddine Bettache ${ }^{1}$, Nawel Boucherba ${ }^{1}$, Laura de Eugenio ${ }^{2}$, Maria \\ Martinez $^{2}$, and Said Benallaoua ${ }^{1}$ \\ ${ }^{1}$ University of Bejaia \\ ${ }^{2}$ Centro de Investigaciones Biológicas, Consejo Superior de Investigaciones Científicas
}

November 25, 2020

\begin{abstract}
Plant biomass constitutes the main resource of renewable carbon in the planet and its valorization has traditionally been focused on the use of cellulose, although hemicellulose is the second most abundant group of polysaccharides on earth. Enzymes involved in its degradation are usually glycosyl hydrolases and filamentous fungi are good producers of these enzymes. In this study, a new strain of Aspergillus niger was utilized for hemicellulase production under solid state fermentation using wheat straw as a single carbon source. Physicochemical parameters for production of an endoxylanase were optimized by using one factor at a time approach and response surface methodology (RSM). Maximum xylanase yield after RSM optimization was increased 3-fold. The enzyme was purified by ultrafiltration and ion-exchange chromatography1.41-fold, with $6.2 \%$ yield. Highest xylanase activity was observed at $50{ }^{\circ} \mathrm{C}$ and $\mathrm{pH}$. A high $\mathrm{pH}$ and thermal stability were found, greater than $90 \%$ residual activity between $\mathrm{pH} 3.0-9.0$ and between $30-40^{\circ} \mathrm{C}$, after $24 \mathrm{~h}$ of incubation, presenting half-lives of $30 \mathrm{~min}$ at 50 and $60^{\circ} \mathrm{C}$. Enzyme was mostly active for wheat arabinoxylan, and displayed the following kinetic parameters $\mathrm{Km}$ of $26.06 \mathrm{mg} * \mathrm{ml}-1$ and Vmax of 5,647 $\mathrm{U}^{*} \mathrm{mg}-1 \mathrm{~min}-1$. Wheat straw xylan hydrolysis with the purified $\beta-1,4$ endoxylanase showed that it was able to release xylooligosaccharides, making it suitable for different applications in food technology.
\end{abstract}

\section{Hosted file}

Manuscript fil.pdf available at https://authorea.com/users/378714/articles/495125optimization-of-\%CE\%B2-1-4-endoxylanase-production-by-a-new-aspergillus-niger-straingrowing-on-wheat-straw-and-application-in-xylooligosaccharides-production 

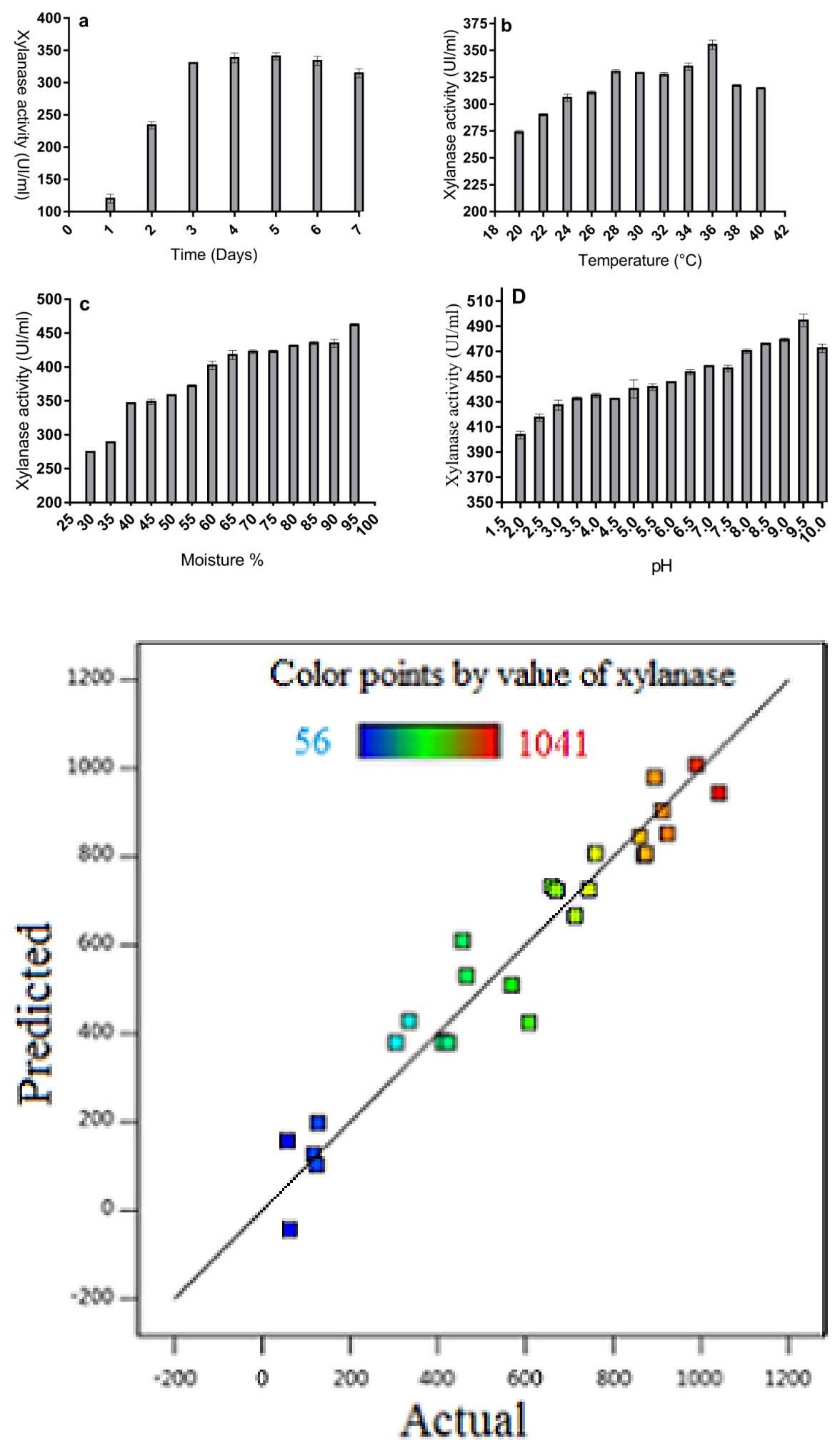

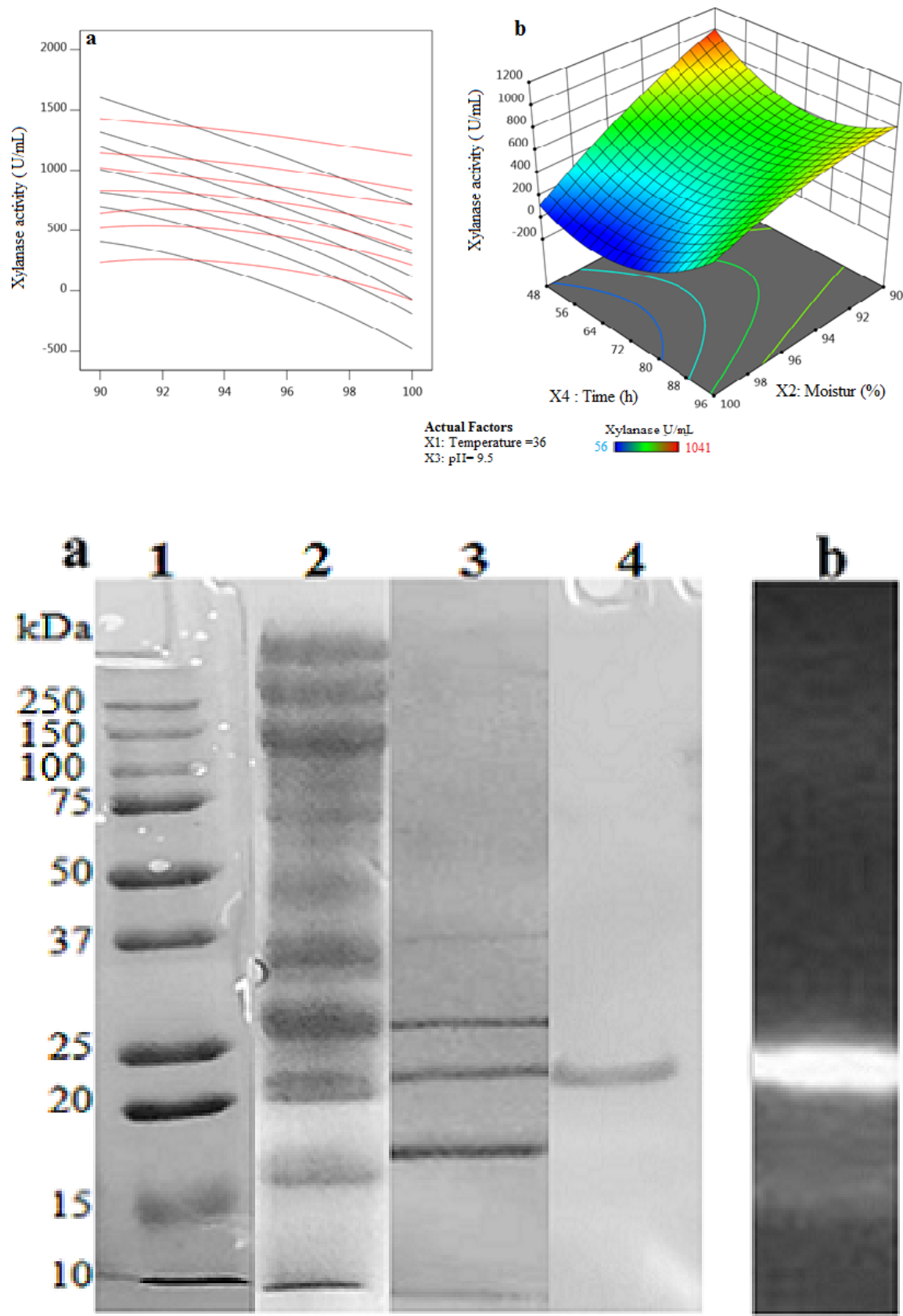

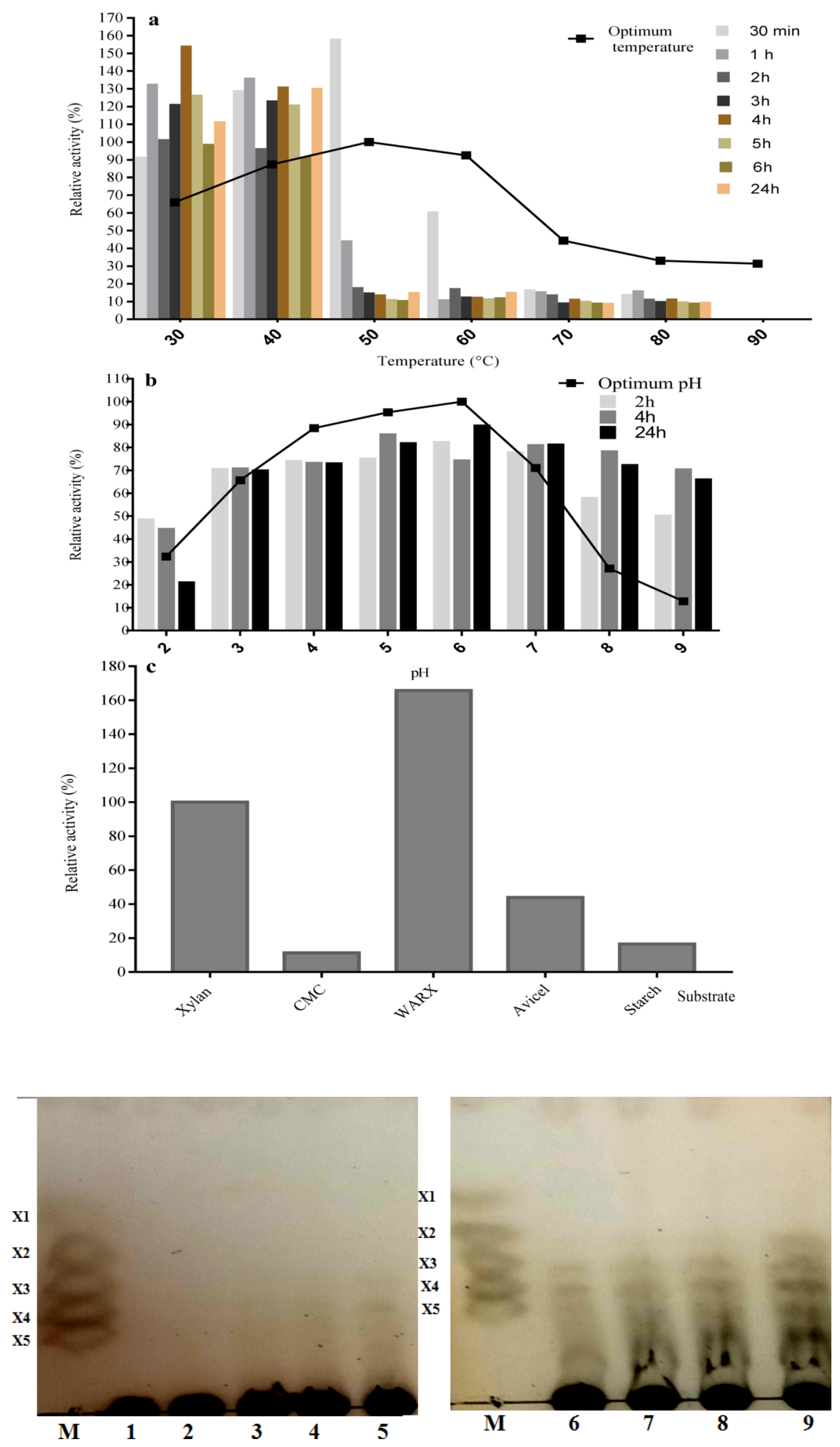